\title{
Indonesian food culture mapping: a starter contribution to promote Indonesian culinary tourism
}

Serli Wijaya(D

\begin{abstract}
The food culture of Indonesia is shaped by several factors such as nature, history, and culture. With its enormous geographic and cultural diversity across the archipelagos, it is evident that Indonesian cuisine is rich in variety and taste. As such, food can be utilised as a strategic means to boost the tourism industry of the country. In the past 5 years, the Indonesian government has given a great support for the development of culinary tourism as one special interest tourism sector that is promoted extensively to the international market. Promoting Indonesian culinary tourism should not be merely exposing the ample varieties of the traditional food that Indonesia has, but more importantly, telling the market about the socio-cultural values behind the food itself. This study aimed to portray how Indonesian food culture has been shaped, developed, and held as the value embedded in the society and has been passed from one generation to the next. For the purpose of the study, a range of literature from journal articles, books, archives, magazines, and articles to Internet sources that are relevant to Indonesian culinary discussions was reviewed.
\end{abstract}

Keywords: Food culture, Indonesian cuisine, Culinary tourism

\section{Introduction}

Food plays a significant part in all aspects of human life, including from fulfilling basic physiological needs to building social interactions and psychological expression [1]. Food has become recognised as an expression of identity and culture and has emerged as one of the popular aspects of cultural tourism [2]. Discussions about food are inseparable from culture. As one of cultural tourism's products, the role of food or culinary tourism has become increasingly important. Culinary tourism is a possible competitive advantage that could be central to destination development, which in turn, can contribute to the overall economic performance [3]. Moreover, local food can be utilised as a tool for differentiating one destination from others in the global marketplace since a country's cuisine exhibits elements of national culture and identity [4].

Considering the size and diversity of the country, it is argued that Indonesia should be able to attract more

\section{Correspondence: serliw@petra.ac.id}

Faculty of Business \& Economics, Petra Christian University, Jalan

Siwalankerto 121-131, Surabaya, East Java 60254, Indonesia international visitors [5]. There are thousands of local foods which potentially offer a strong focal point to portray Indonesia as a tourism destination. Nevertheless, as stated by the Minister of Tourism and Creative Economy of Indonesia, having very diverse traditional dishes at the same time also poses a challenge for the government to select which particular food to be promoted to the international market [6]. There has been an imbalance in cuisine exposure across regions in Indonesia, giving the largest focus still on the food of Java and Sumatra. As a consequence, many non-Indonesians are unaware that other regions of Indonesia apart from those two have their own distinct cuisine [7]. A review of literature has shown that most references about Indonesian cuisines are dominated with popular cooking articles or books containing the recipes as to how to prepare and serve the dishes. This paper, therefore, can be seen as one of a few scholarly attempts to introduce the Indonesian food culture to the broader academic audiences. For the purpose of the study, the remainder of this paper is structured as follows. The following section presents food as part of the culture and different values associated with food. Next, a detailed

(c) The Author(s). 2019 Open Access This article is distributed under the terms of the Creative Commons Attribution 4.0 International License (http://creativecommons.org/licenses/by/4.0/), which permits unrestricted use, distribution, and 
review about Indonesian food culture is provided containing the history and the evolving stages of Indonesian food culture. The last section provides a comprehensive description about the characteristics of Indonesian cuisines followed by the typology of Indonesian food culture as presented in both narrative and visual ways.

\section{Food and culture}

The term culture is used in a variety of ways. Culture is a key concept in our knowledge of societies both past and present, and its definitions are constantly being developed and refined [8]. From the perspectives of sociology and anthropology, culture is being defined as all that is learned, shared, and transmitted amongst groups of human beings from generation to generation [9]. Specifically, culture can also be defined as the values, beliefs, attitudes, and practices accepted by members of a group or community [10]. The culture of a particular society is manifested in various ways, in its art, language, literature, music, and in all forms of religious and secular ritual [11]. The elements of culture can be categorised into two: first, observable elements, such as the observable characteristics of behaviour, material arts, food, language, and social arrangements, and second, the nonobservable elements, such as the beliefs, attitudes, and values held by most people in a society [12]. Also included in the category of non-observable elements are role perceptions, stereotypes, categorizations, evaluations, expectations, memories, and opinions. Members of a similar culture have similar values; conform to similar rules and norms; develop similar perceptions, attitudes, and stereotypes; use common language; and participate in similar activities [13].

The process of how culture is learned and passed through different generations via language acquisition and socialisation is called enculturation [10]. One of the most significant examples of this learning process in societies relates to food. Food habits are a culturally standardised set of food-related behaviours that are expressed by individuals who have grown within a given cultural tradition [14]. Food habits can be seen as the ways and rules by which people use food from how the food is selected, obtained, and distributed, to who prepares, serves, and eats it [10]. These ways and rules are shaped by multi factors, such as natural resources (e.g. climate, land, and water), belief (religion and education), ethnicity (indigenous or immigrant), technological advancement (e.g. hunting, agricultural, fishing), and colonisation [15].

Food culture can be viewed as a product of codes of conduct towards acceptable or unacceptable foods and within a particular social group [16]. It also sets up the structure of social relationships between members of a society [17] and is a daily reaffirmation of cultural identity through symbolic meanings of ritual, traditions, and special occasions within the social group [10]. That is, food culture in one place will be different from the others.

Food is considered to be a cultural practice that distinguishes one culture from another [18]. When viewed in detail, it is clear that there are observable cultural differences: in the basic ingredients from which food is prepared; the ways in which it is preserved, prepared, and cooked; the amount and variety available at each meal; the tastes that are liked and disliked; the customs and traditions of serving food; the implements and utensils which are used; and certain beliefs about the properties of particular foods. Further, techniques used for the serving and consumption of food also vary cross-culturally [11]. For instance, in some cultures, it is proper to eat using one's fingers, whilst convention in others requires the use of implements. Differences are also evident in eating patterns. Many people, for example, have only two meals a day, whilst others have one big meal, snacking at other times. Some like their food hot, and others like it cold. Regardless of these distinctions, however, it is suggested that all such cross-cultural differences are learned.

As a component of culture, food has a significant role in shaping individual as well as a cultural group's foodways. At an individual level, food can portray selfidentity [19] and self-expression [10], whereas in a broader context, food echoes the identity that distinguishes one culture from another [20]. Even more, it is suggested that to understand a culture, an individual must experience its food [18].

\section{Values associated with food}

As a manifestation of culture, food entails both technical and symbolic functions within a particular cultural group [21]. Technically, food functions as the fulfilment of basic human physiological needs [9]. From the consumer behaviour viewpoint relating to consumption values [22], this type of eating behaviour occurs for utilitarian or instrumental reasons, which are to satisfy hunger and moreover to meet the nutritional needs of the body.

Discussing about food is not merely about nutrition [23], rather, consuming food is also associated with hedonistic reasons such as seeking fun, pleasure, and sensory stimulation [22]. Food can function as a symbol of social unity. For example, it can be used to strengthen family bonding, develop friendships, and to provide hospitality when members and/or non-members of the group eat together [24]. Furthermore, food represents ethnic, regional, and national identities. Food habits have been used as an important, or even determining, criterion for anthropologists studying cultures [10]. Those from a common culture share the same assemblage of food variables and vice versa $[17,25]$. In the context of 
eating out, food functions as a symbol of lifestyles and is a distinctive aesthetic feature of modern societies [26]. People often value the sociability function of food and meals more than the quality of the food [27].

The opportunities to dine out together may increase during trips where dining plays a stronger social function amongst visitors, their family members, and/or friends, and destination residents such as local community and tourism service personnel [28]. For some visitors, food offers an entertainment function where it is one of the most enjoyable activities undertaken during travel. This allows visitors to pursue their motivations of relaxation seeking, excitement, and escapism [29]. Food is a gateway for visitors to really learn about another culture by experiencing new food in a destination that differs from what they have at home in terms of ways of cooking, presenting, and eating [11]. Local cuisine serves as a major means for visitors to appreciate the culture of a destination [16]. In this sense, food plays a role as a novel learning experience for visitors. Beyond this learning process, eating is a symbolic act, meaning that consuming local food means consuming another culture or geographical location in order to incorporate it into one's own identity [30].

\section{Indonesian food culture}

The food culture of Indonesia is shaped by several factors such as nature, history, and culture. Geographically, Indonesia is the largest archipelago country in the world with 17,508 islands. Its tropical climate and high humidity support a rich and unique blend of diverse natural resources including beaches, volcanoes, tropical forests, and wildlife. The country is within the so-called Pacific 'Ring of Fire', the meeting point of two of the earth's tectonic plates which gives rise to frequent seismic activity which in turn produces fertile ash over the land [31]. To a large extent, the western islands of Indonesia are lush and green: Borneo has rainforests and swampy coastlines and Java and Sumatra, whose volcanos are many, abound with fertile gardens, coconut groves, paddy fields, fastflowing rivers, and beaches. On the other hand, the eastern islands of the archipelago, such as Nusa Tenggara (from Lombok East to Timor), is rocky and semi-arid and is characterised by dry seasons that are longer and harsher. Sulawesi (the Celebes) has a variety of climates and different parts receive their monsoon rains at different times of the year. Further east, the 'Spice Islands of Maluku' (the Molucas) conform to the image of the lush tropics, whilst Papua (west part) has everything from swamps to rainforests [7].

The seas and straits which surround the islands are at least as important as the country itself. This is reflected in the way Indonesians speak not only of 'our land' but also 'our land and water' (in Indonesian language: tanah air kita) [32]. As its endless coastlines are strategically located between two oceans, Indonesia enjoys an abundance of saltwater fish and seafood. Its many lakes and rivers provide freshwater fish. Not surprisingly, fish, which is usually smoked, grilled, baked, or cooked, is a major source of protein for the people of Indonesia [33].

Indonesia has a striving agriculture industry with sugar as the largest commercial crop. Improved agricultural techniques during the 1980s and the 1990s have made it possible for the country to grow enough rice to meet its local demands. The country is considered as the world's third largest producer of coffee (after Brazil and Colombia), and the second largest producer of palm oil after Malaysia [34] (Fig. 1).

With regard to the culture, Indonesia holds cultural richness and diversity with more than 1340 tribes, most with their own language and dialects [35]. A seminal study conducted by Statistics Indonesia in cooperation with the Institute of Southeast Asian Studies (ISEAS) in 2013 reported that there were 633 major ethnics in Indonesia. Javanese and Sundanese are the two largest ethnicity groups in the country holding $40.05 \%$ and $15.50 \%$ of the total population, respectively [36]. Each ethnicity has its own local food leading to a diverse character and uniqueness. There are different ways to prepare the food (i.e. ingredients used, cooking methods, cooking utensils applied), to serve the food (i.e. types of cutleries used and food presentation), as well as the way to eat the food [37].

\section{Indonesian culinary development}

Indonesia's food culture cannot be separated from the country's long history. In relation to this, culinary development in Indonesia can be categorised into at least three phases: (1) original phase, (2) multicultural phase, and (3) contemporary phase [37]. Each phase has distinctively way as to how the food is being prepared, being presented or served, and being consumed or eaten which, in turn, shapes a strong basis for the establishment of the Indonesian food culture. This food culture is learned, shared, and passed from one generation to another and whilst some foodways have been refined and adapted, the majority are still applied until today.

\section{Original culinary phase}

The first phase, called the original culinary phase, occurred during the periods of the great Indonesian kingdoms from the Hindu Kutai kingdom in Kalimantan $(400 \mathrm{AC})$ to the Islamic Banten kingdom in West Java (1156-1580 AC). The word original indicates the food culture in this phase is a reflection of how indigenous people undertook food-related activities ranging from food acquisition and preparation to food consumption without the influence of other nations. The ingredients 


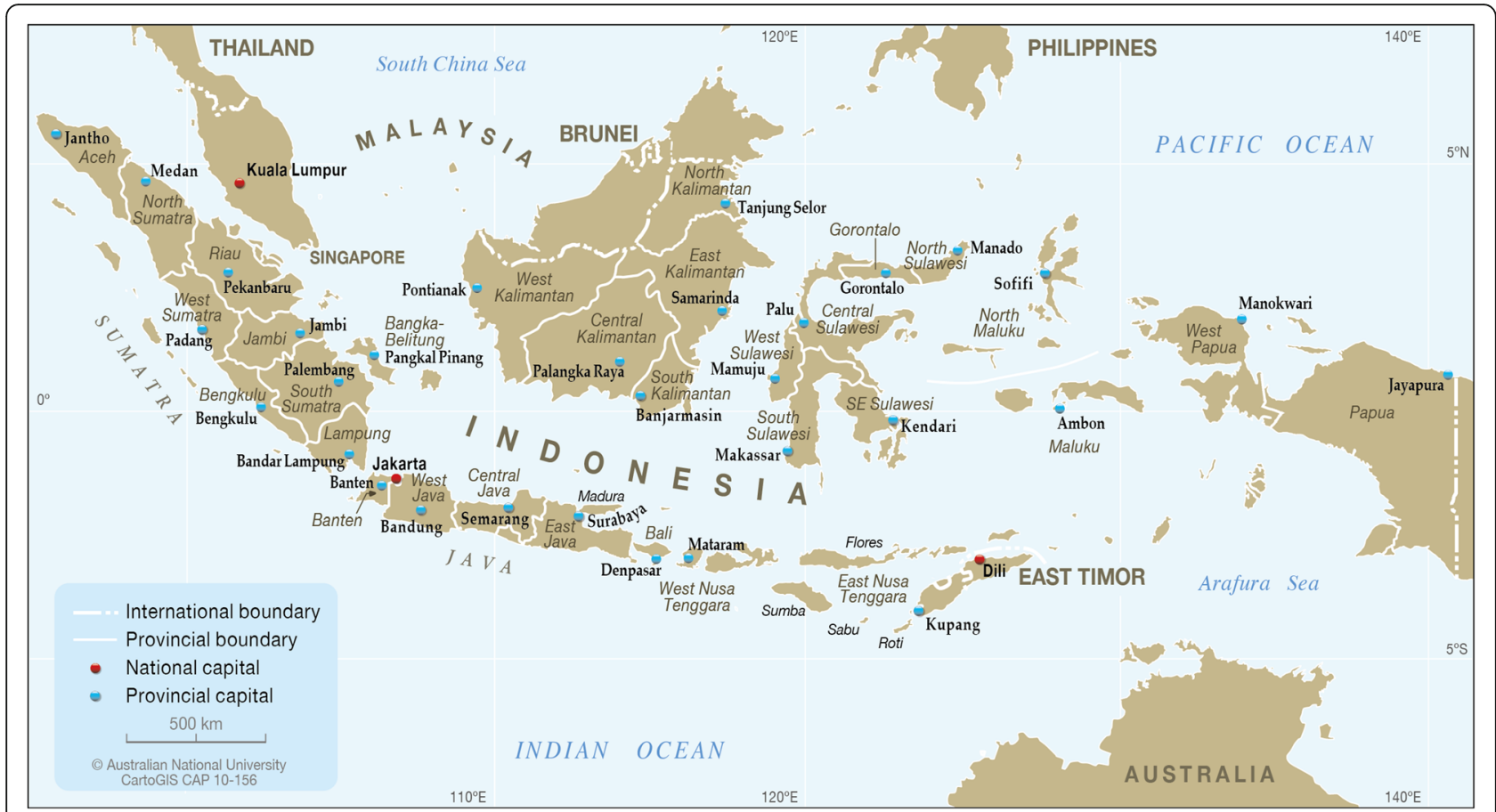

Fig. $1 \mathrm{Map}$ of the Indonesian archipelago. The islands of Indonesia are also known as the Indonesian archipelago. The islands comprise the nation-state of Indonesia or to the geographical groups which include its islands. Indonesia has 17,508 officially listed islands within the territory of the Republic of Indonesia. This makes Indonesia the world's largest island country. Indonesia is an archipelagic country located in Southeast Asia, lying between the Indian Ocean and the Pacific Ocean. It is located in a strategic location astride or along major sea lanes connecting East Asia, South Asia, and Oceania. As an archipelagic country, Indonesia extends about $5120 \mathrm{~km}$ (3181 mi) from East to West and $1760 \mathrm{~km}$ (1094 mi) from North to South (picture was retrieved from URL http://www.goway.com/asia/indonesia/index.html)

used to prepare the dishes were taken from the surrounding natural resources whilst the cooking technique employed was relatively simple and the majority used hand-made wooden or stone cooking utensils. During this period, the most popular dishes were being steamed, wrapped in banana leaves, with the main ingredients as rice and cassava [37].

\section{Multicultural culinary phase}

The second multicultural culinary phase was characterised by the influence of cooking art brought by successive waves of traders from Europe, India, Middle East, and China [37]. Due to the archipelago's strategic location, trade with other nations was established and eventually became one of the most important factors in the country's history. European traders came to Indonesia in the sixteenth century seeking to control the area's precious spices, including nutmeg, cloves, cubed pepper, and others. The Portuguese arrived first in 1512 but were soon followed by the Spanish, the British, and finally, the ones who became the dominant players, the Dutch [7]. The arrivals of these traders had a significant influence on the food culture of Indonesia. Given the fact that the Dutch colonised the archipelago for more than 300 years, this brought in Dutch culture, influencing the Indonesian's life in many ways including the food culture, including the way the local cuisines are prepared and named. For instance, the rijsttafel ('rice table'-many dishes served on the table with a rice centrepiece) has long been popular as a prominent symbol of colonial eating in Indonesia [32] (Fig. 2).

Cultural assimilation as an impact of colonialism and migration in terms of different ways of preparing, cooking, presenting, and consuming the food between the local people and the immigrants was something inevitably taking place [9]. In Indonesian culinary history, this is also the case, for example, the Indian influences can be seen mostly in Sumatran cuisine featuring curried meat and vegetables in which herbs such as cloves and nutmeg are used following the Indian traditions. In addition, the satay-the method of preparing pieces of meat (lamb or goat) on skewers-is considered as the most noticeable example of Arabic influence on Indonesian food culture; however, the marinades and peanut sauce with which satay is served originates from Java [32]. The European colonists contributed in bringing and introducing chillies to Indonesia, which became one of the key signature characteristics of Indonesian food. They had, in turn, originally been brought by the Spanish and Portuguese from other colonies in South 

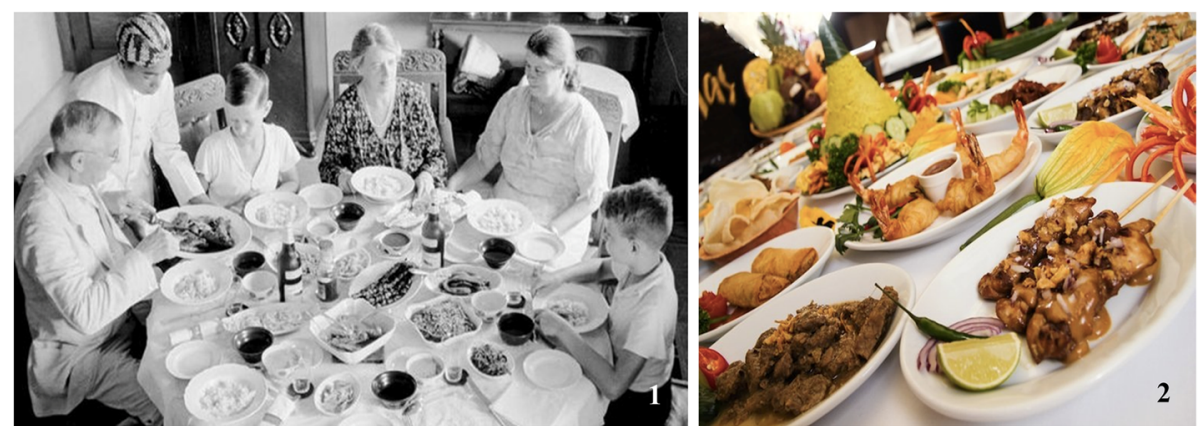

Fig. 2 a The rijsttafel. It is a Dutch word that literally translates to 'rice table' and is an Indonesian elaborate meal and serving ritual introduced by the Dutch during their colony in Indonesia in the early of the nineteenth century. The ritual involved many servers who passed around a large number of various dishes from rice, meats, and vegetables and served the guests. The classic style rijsttafel involved serving of up to 40 different dishes by 40 male waiters. Rijsttafel was initially a symbol of high status; therefore, it is symbolised by the abundance and variety of dishes being displayed and served. $\mathbf{b}$ The rijsttafel in today's Indonesian dining style. Indonesians adopted rijsttafel as part of daily dining practice where all dishes are being served altogether on the dining table. In contemporary Indonesian cuisine, rijsttafel has been adapted into a western style or buffett style (retrieved from https://www.merdeka.com/gaya/rijsttafel-kuliner-indonesia-belanda-yang-terlupakan.html)

America [32]. Other vegetables such as potatoes, tomatoes, pumpkins, cabbage, cauliflower, and carrots came from Europe too [31]. The influence of Chinese cuisine can be seen in hundreds of Indonesian dishes with Chinese origin, such as noodles, which have been adapted to the local taste, customs, and the available ingredients [7].

Moreover, during trading periods, Hinduism, Buddhism, Christianity, and eventually Islam were brought to Indonesia, and as a consequence, the introduction of these religions to the local people had its own influence on the development of food culture. For example, nasi tumpeng kuning-a large cone-shaped steamed rice coloured yellow with turmeric and rich garnished-is traced back to ancient Hindu beliefs. The shape symbolises that of the mythical Hindu mountain, Meru, whilst yellow, one of the four sacred colours for Hindus, is the colour of royalty as well as of worship [7]. Therefore, for most Indonesian people, rice is not only the most important basic food but it is also regarded as sacred and therefore has great symbolism in various rituals. It is the manifestation symbol of Dewi Sri, the Hindus' goddess of prosperity and fertility [38]. Rice growing in turn often decides the rhythm of daily life; for example, weddings are often held after the harvest period. Until today, nasi tumpeng kuning is often served at special occasions and at opening ceremonies as a symbol of good fortune, wealth, and dignity. The most important person cuts the tip of the cone and serves it to an older person who is held in high regard [32] (Fig. 3).

Another evidence of the religious influence on Indonesian food culture can be seen from different meats used across the country. The majority of the Indonesian population is Moslem and as part of their religious beliefs, they are not allowed to eat pork. Consequently, chicken and beef are amongst the most common meats cooked in Indonesian cuisine. By contrast, on the island of Bali where $90 \%$ of the population are Hindu, people there do not eat beef. Instead, pork is often found in many Balinese traditional dishes [7].

\section{Contemporary culinary phase}

The final phase is the contemporary culinary phase where the food habits of Indonesian people have been pretty much influenced by the rapid development of

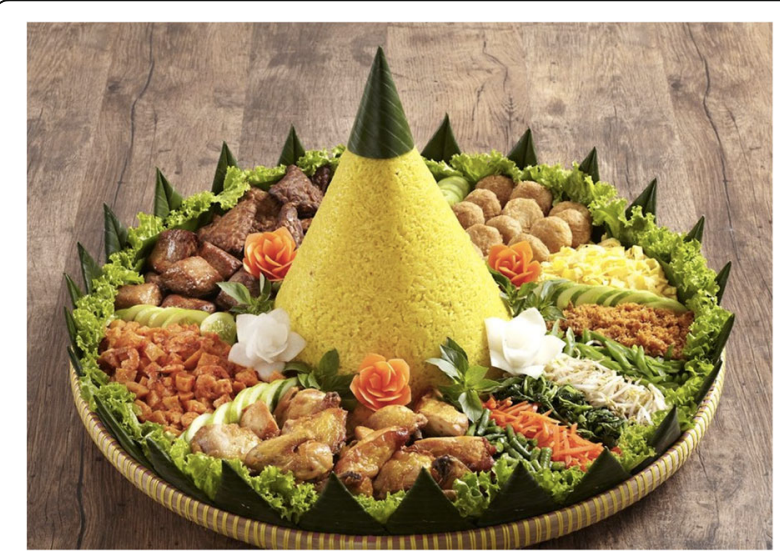

Fig. 3 Nasi kuning tumpeng. Nasi tumpeng is a large cone-shaped yellow steamed rice dish with side dishes of vegetables and meat originating from Javanese cuisine of Indonesia. It is traditionally featured in a religious ceremony as a symbol of thanksgiving to gods of nature. Nasi tumpeng comes from an ancient Indonesian tradition that revers mountains as the abode of the ancestors and the gods. Rice cone is meant to symbolise the holy mountain. The feast served as some kind of thanksgiving for the abundance of harvest or any other blessings. In today's society, nasi tumpeng is a common dish served in various events of corporates, personal, and other organisations, holding the same philosophy for gratitude expression (picture was

retrieved http://nasikentjana.com/menu-nasi-tumpeng/) 
global food service chains [37], starting with Kentucky Fried Chicken (KFC) which opened its first outlet in the mid-1980s, to the subsequent expansion of McDonald's from 1991. Since then, hundreds of global food service brands have proliferated and in many ways have shaped local eating-out lifestyles. Further, as an impact of globalisation, restaurants that offer what so-called 'modern' international cuisines such as Japanese, Thai, Indian, and French have grown dramatically in the country, both operated by global and local business players. Ironically, in the contemporary phase, traditional food appeared to be put aside since more people prefer to consume what they call 'modern' food. However, in the past few years, the government has taken an impressive initiative to promote Indonesian traditional culinary and reappreciate the traditional food of the country. To do so, relevant stakeholders such as industry association, business practitioners, and educational institutions have been invited to step in to actualise and promote Indonesian culinary both to domestic and international markets. Indonesian cuisine has regained its popularity amongst Indonesian people: traditional food is not just sold at local food street hawkers (called warung), but there are growing numbers of medium-large scale restaurants which specialise in traditional Indonesian food [39].

\section{Characteristics of Indonesian cuisine \\ Pre-food consumption: ingredients, cooking methods and utensils}

As abovementioned, Indonesian cuisine characteristics are heavily influenced by natural and cultural conditions. Basic ingredients of Indonesian cuisine consist of a variety of herbs, seasoning, and spices. Most Indonesian dishes use fresh herbs such as onion and garlic, spring onion, ginger roots, turmeric, galangal, candlenuts, lemon basil, lemon grass, and not to mention chilli [7]. In addition to these fresh herbs, the inclusion of spices is at the heart of almost every Indonesian dish. Known as islands of spices, the spices available range from seed, fruit, root, bark, or vegetative substance, and the most common include coriander seeds, pepper, nutmeg, cumin, and cloves. Either grated, chopped, or dried, these spices, together with other fresh ingredients, play a part as a seasoning for the purpose of flavouring the food (in Indonesian language, it is called bumbu) [32]. Besides for cooking, the spices are extensively used for other purposes such as to preserve the food, as a medicine, part of the rituals, and ingredients of cosmetics and perfumery [40] (Fig. 4).

In regards to the cooking method, Indonesian food is prepared according to a variety of ways, being shallow or deep fried, grilled over hot coals, simmered, steamed and

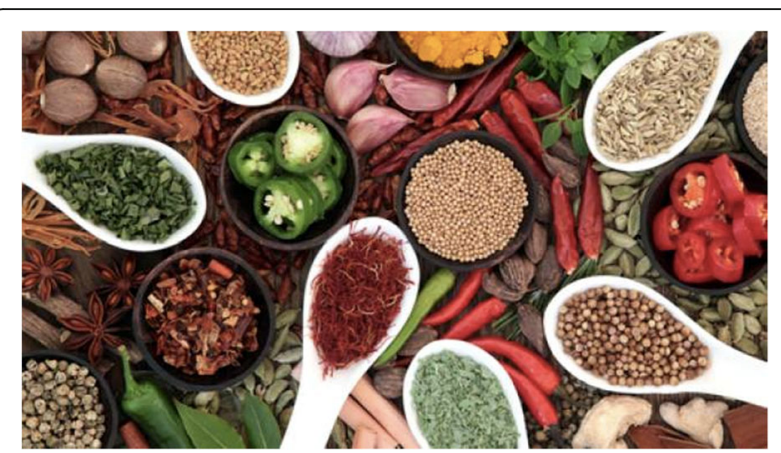

Fig. 4 Authentic Indonesian spices and herbs. Indonesian cuisine is rich in herbs and spices. Known throughout the world as the 'Spice Islands', the Indonesian islands of Maluku contributed to the introduction of its native spices to world cuisine. Pala (nutmeg), cengkih (clove), daun pandan (pandan leaves), keluak (Pangium edule), and lengkuas (galangal) are considered as the native and authentic spices of Indonesia. Whilst some spices such as chilli, shallot, garlic, pepper, ginger, turmeric, and galangal can be found throughout the country, several spices are only found in a specific region. The Western region uses more spices than the Eastern part of Indonesia (retrieved

from https://www.suara.com/lifestyle/2018/05/10/130000/bumbumasak-asli-indonesia-diekspor-sampai-ke-amerika)

baked, and relatively speaking, does not require complex kitchen utensils [32]. Its basic cooking utensils include mortar and pestle, chopping board, cleaver, wok (wajan), spatula, ladle, and steamers, with wok and mortal-pestle considered as the most characteristic. Whilst the wok is used to fry the food, a flat saucer-shaped granite grinding stone together with a granite pestle is frequently used to grind or crush the fresh herbs and spices and make them into spice paste (bumbu). Unlike neighbouring Malaysia and Thailand where the ingredients are pounded with a pestle inside a deep mortar, the Indonesian people rub or grind ingredients with a backwards and forwards motion across the granite [7]. Also widely used in Indonesian cooking is the banana leaf, either for wrapping food for grilling, steaming, or placing directly onto hot coals. Banana leaf can be found abundantly in Indonesia's tropical islands and the use of the leaf as a wrapper contributes authentic flavour and aroma on the food. There are different ways of wrapping the food in banana leaf, depending on the contents and particular style of preparation [7] (Fig. 5).

\section{During food consumption: meals and ways of eating}

The traditional Indonesian meal does not involve courses that are served individually such as entrée, main, and dessert. Instead, each dish is handed out collectively [41]. All food is served on the table, given the influence of Dutch culture-the rijsttafel or rice table. Rice (nasi) is central to the lives of Indonesians [7]. It is considered as the most popular staple food for the majority of the population although in some regions, there are 


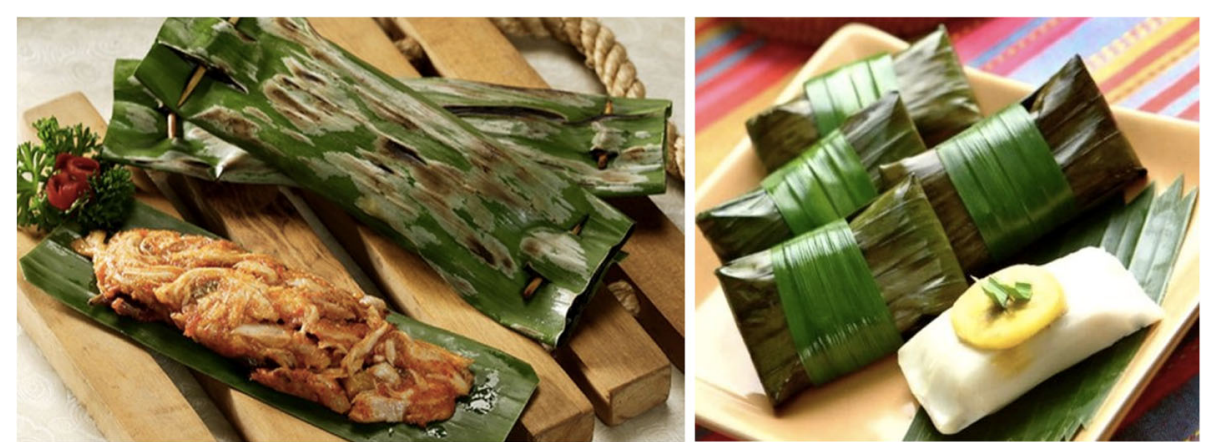

Fig. 5 a Pepes. Pepes is a steamed fish dish with spices, wrapped in banana leaf as a food wrapping. The banana leaf package containing food is secured with lidi (a small nail made from central rib of coconut leaf) on the left and right sides of the wrap. The cooking method of pepes is steamed or grilled on charcoal. Such a cooking technique allows the rich spice mixture to be compressed against the main ingredients inside the individual banana leaf package whilst being cooked, and also adds a distinct aroma of cooked or burned banana leaf. Although being cooked simultaneously with food, the banana leaf is a non-edible material and is discarded after cooking. $\mathbf{b}$ Nagasari. Nagasari is a traditional steamed cake and considered as a snack. It is made from rice flour, coconut milk, and sugar, filled with slices of banana. Nagasari is usually wrapped in banana leaves before being steamed, or added with pandan leaf to enhance the aroma (retrieved

from https://www.google.com/search?safe=strict\&tbm=isch\&q=aneka+masakan+dibungkus+daun+pisang)

variations, for example, sago palm in Maluku islands and corn in Madura island and some eastern islands [40]. The rice is eaten accompanied by one or two main savoury dishes consisting of meat such as chicken or beef, fish, and vegetables [32]. Besides the rice and side dishes, it is common to have condiments which include chilli-hot sambal as well as something to provide a crunchy contrast such as deep-fried tiny anchovies (ikan teri), tapioca crackers (krupuk), or deep-fried tempeh [7]. Tempeh is an adaptation of tofu to the tropical climate of Indonesia. It is originally developed in Java since the 1700 s and made through a controlled fermentation process that binds soybean into a cake form. The fermented soybean holds more protein, dietary fibre, and vitamins than regular tofu, and it is widely consumed either as snack or part of meal across the country [42].

Having rice as the base of most Indonesian meals, the typical Indonesian menu is high in fibre, complex carbohydrates, and monounsaturated fatty acids. Breakfasts consist of rice, noodles, or meat and vegetable soup, accompanied by Java coffee or tea to start the day. Lunch is the main meal of the day. The meal is prepared all in the morning and is served all at once. Dinner is often eaten after the workday has ended. Lunch and dinner normally contain staples, meat or fish, vegetables, and condiments [41].

Indonesian meals are commonly eaten with the combination of a spoon in the right hand and fork in the left hand, although in many parts of the country, such as in Java, it is common to eat with one's hands. The use the right hand is an acceptable custom since the left hand is considered unclean in Moslem religion beliefs. Eating with chopsticks is generally only found in food stalls or restaurants serving Indonesian adaptations of Chinese cuisine. Selamat makan is the polite Indonesian invitation before the meal consumption [7].

\section{Classification of Indonesian cuisine}

With its enormous geographic and cultural diversity, it is evident that Indonesian cuisine is rich in variety and taste. For example, in using fresh herbs and spices, each part of Indonesia develops its own combinations and intensities to produce a food taste that is either spicy, hot, strong, sweet, sour, or a mixture of these flavours [31]. Basically, Indonesian cuisine can be classified based on six major islands across the country. Each has different food culture characteristics that are shaped by the natural conditions, history, and culture of the region.

The food in Sumatra Island is much influenced by Indian and Chinese culture. Through its roots in the spice trade era and strategic location in the India-China trade routes, most Northern Sumatra cities exhibit the influence of Chinese and Indian immigrants' ways of life [40]. As the western anchor of the archipelago, Sumatra was the first port of call for Indian and Arab traders, and the coastal Sumatrans heavily adopted their spices as well as stews, curries, and kebabs from these merchants [31]. The most popular cuisine from the island is Padang (West Sumatra) food whose signature dish is rendang-a spicy stewed beef in coconut milk [43]. In 2011, an online polling undertaken by CNN to 35,000 'love-food' readers across the globe voted rendang as the top 50 world's most delicious foods [44]. Moreover, the Padang food restaurant chains can be found throughout Indonesia and neighbouring countries such as Malaysia and Singapore, thus making Padang as one of the most favourite Indonesian regional cuisines amongst international travellers [45]. 
Table 1 Indonesian food culture mapping

\begin{tabular}{|c|c|c|c|c|c|c|}
\hline \multirow{3}{*}{$\begin{array}{l}\text { Characteristics } \\
\text { Natural } \\
\text { environment: } \\
\text { geographical } \\
\text { position, } \\
\text { temperature, } \\
\text { landscapes }\end{array}$} & \multicolumn{2}{|c|}{ Western part of Indonesia } & \multicolumn{2}{|c|}{ Central part of Indonesia } & \multicolumn{2}{|c|}{ Eastern part of Indonesia } \\
\hline & Sumatera & $\begin{array}{l}\text { Tropic, hot, humid, many } \\
\text { volcanoes, fertile, green, lush, } \\
\text { many paddy fields. }\end{array}$ & Kalimantan & $\begin{array}{l}\text { - Tropic, hot, humid. } \\
\text { - A lot of rainforests } \\
\text { - Swampy coastlines }\end{array}$ & $\begin{array}{l}\text { East } \\
\text { Nusa } \\
\text { Tenggara }\end{array}$ & Hot and drier \\
\hline & \multicolumn{2}{|l|}{ Java } & \multirow[t]{3}{*}{ Sulawesi } & - Many big and long rivers & Maluku & $\begin{array}{l}\text { - Contains of } \\
\text { hundreds of small } \\
\text { islands } \\
\text { - Hot and humid but } \\
\text { fertile for spices to } \\
\text { grow (known as } \\
\text { Spices Islands). }\end{array}$ \\
\hline & Bali & & & & West & - Hot and drier, but \\
\hline & $\begin{array}{l}\text { West } \\
\text { Nusa } \\
\text { Tenggara } \\
\text { (Lombok) }\end{array}$ & $\begin{array}{l}\text { Tropic, hot, humid, fertile and } \\
\text { green although in some parts are } \\
\text { drier. }\end{array}$ & & & Papua & $\begin{array}{l}\text { some parts of the } \\
\text { regions have snowy } \\
\text { mountains. } \\
\text { - A lot of rainforests } \\
\text { and swampy } \\
\text { coastline. } \\
\text { - Many rivers and lakes }\end{array}$ \\
\hline \multirow[t]{4}{*}{$\begin{array}{l}\text { Socio-cultural: } \\
\text { Major ethnic } \\
\text { groups, religion }\end{array}$} & Sumatera & $\begin{array}{l}\text { - Acehnese, Bataknese, } \\
\text { Padangnese, more Chinese groups } \\
\text { in North Sumatera. } \\
\text { - The majority are Muslims, except } \\
\text { Bataknese are mainly Christian. }\end{array}$ & Kalimantan & $\begin{array}{l}\text { - Dayak, Banjar, and Chinese } \\
\text { - The majority are Muslims }\end{array}$ & $\begin{array}{l}\text { East } \\
\text { Nusa } \\
\text { Tenggara }\end{array}$ & $\begin{array}{l}\text { - Timorese } \\
\text { - The majority are } \\
\text { Christian and Catholic }\end{array}$ \\
\hline & Java & $\begin{array}{l}\text { - Javanese, Sundanese, Madurese. } \\
\text { - The majority are Muslims. }\end{array}$ & \multirow[t]{3}{*}{ Sulawesi } & \multirow{3}{*}{$\begin{array}{l}\text { - Minahasan, Bugis, Torajan } \\
\text { - The majority are Muslims } \\
\text { except for Minahasan, the } \\
\text { majority are Christian. }\end{array}$} & Maluku & $\begin{array}{l}\text { - Ambonese } \\
\text { - The majority are } \\
\text { Christian and Catholic }\end{array}$ \\
\hline & Bali & $\begin{array}{l}\text { - Balinese } \\
\text { - The majority are Hindus. }\end{array}$ & & & \multirow[t]{2}{*}{$\begin{array}{l}\text { West } \\
\text { Papua }\end{array}$} & \multirow{2}{*}{$\begin{array}{l}\text { - Some indigenous } \\
\text { ethnic groups are still } \\
\text { practising a very } \\
\text { traditional ways of } \\
\text { live. } \\
\text { - The majority are } \\
\text { Christian and Catholic }\end{array}$} \\
\hline & $\begin{array}{l}\text { West } \\
\text { Nusa } \\
\text { Tenggara } \\
\text { (Lombok) }\end{array}$ & $\begin{array}{l}\text { - Sasak ethnic group. } \\
\text { - Half are Hindus and the rest are } \\
\text { Muslims. }\end{array}$ & & & & \\
\hline $\begin{array}{l}\text { Food: Staple food, } \\
\text { spices/herbs, main } \\
\text { ingredients, }\end{array}$ & Sumatera & $\begin{array}{l}\text { - The influence of Middle East and } \\
\text { Indian culture are strong in the } \\
\text { regions. }\end{array}$ & Kalimantan & $\begin{array}{l}\text { - Rice is the staple food. } \\
\text { - Freshwater fish is abundant. }\end{array}$ & $\begin{array}{l}\text { East } \\
\text { Nusa } \\
\text { Tengqara }\end{array}$ & $\begin{array}{l}\text { - Corn and cassava is } \\
\text { the staple food }\end{array}$ \\
\hline
\end{tabular}

- The cuisines have a very strong flavour (spicy, sour, thick that comes from heavy usage of coconut milk in cooking the dishes).

- Rice is the staple food.

- Beef, chicken as meats used in the dishes, along with vegetables. - For Chinese and some Christian Bataknese, pork is eaten.

Java

- Rice is the staple food. Maduranese eat corn as their main food.

- Beef, chicken as meats used in the dishes along with vegetables. - Foods are sweeter in Central Java and the opposites in East Java.

Bali - Rice is the staple food.

- Pork is common in Balinese cuisine.

- Many Balinese dishes are spicy.

West - Rice is the staple food.

Nusa - The signature flavour of Lombok

Tenggara cuisine is spicy.
- Rice is the staple food.

- North Sulawesi cuisine has a very strong and spicy flavour; also some dishes contain extremely unfamiliar ingredients.

- Freshwater fish and seafood are abundant.

- Known as the best seafood produce in Indonesia.
Maluku - Corn and cassava is the staple food, some eat papeda as the main food.

- Seafood is the main ingredients of the foods.

- Land of spices and fresh herbs

West $\quad$ Corn and cassava is

Papua the staple food, some eat papeda as the main food.

- Seafood is the main ingredients of the foods. 
Javanese cuisine is strongly influenced by the island's traditional kingdoms such as Mataram in Central Java and Majapahit in East Java. Also named as a royal cuisine, most of Javanese cuisine is considered relatively mild compared to other regions of Indonesia [33]. In Java Island, the major ethnic groups are Javanese (70\%) who live in Central Java and East Java provinces; Sundanese in the western of the island (20\%); and Madurese (10\%), who inhabitant the island of Madura in the eastern part of Java. There are diverse patterns of cuisine across the regions in the island. Sundanese cuisine uses a lot of fresh vegetables in its dishes [31]. Further, food in Central Java is distinguished for its sweetness whereas East Javanese cuisine tends to be less sweet and spicier compared to Central Java's. In addition, seafood products are widely used in this region to make shrimp paste condiment, an ingredient found in many East Javanese dishes [40].

Then there are Bali and West Nusa Tenggara (Lombok) cuisines. Unlike central and western regions of Indonesia, Nusa Tenggara whose climate is drier, it is more common to have sago, corn, cassava, and taro rather than rice, as staple food [46]. Since the vast majority of the population in Bali is Hindu, this religious belief has reflected greatly the way Balinese cuisine is prepared; for instance, beef is very rarely used whilst pork is more common. On the other hand, although West Nusa Tenggara is in close proximity with Bali and the island was ruled by a Hindu Dynasty from Bali, however, a revolt in 1891-1894 left the entire island to the Netherland East Indies colony. As a result, there is a mixture of cuisines wherein some are close to those in Bali (Hindu's influence) and the others have a touch of Dutch influence in taste [40].

The cuisine from Kalimantan, the Indonesian region of Borneo island that is located at the centre of maritime South East Asia, is appealing too. Its sweeping coastlines and many large rivers provide an abundance of seafood and freshwater fish used in the local dishes [47]. In addition to this, there are three major ethnic groups in Kalimantan including the Dayak (indigenous inhabitants of Borneo), Malay, and Chinese which make up about $90 \%$ of the total population [40]. These distinct groups support the diversity of the cuisines across the island. A big percentage of Chinese community lives in the west of Kalimantan and it is unsurprisingly that cuisine in this region is dominated by Chinese-related ingredients such as noodles, soy sauce, and pork. On the other hand, at the rest of the island, the cuisines have strongly influenced by indigenous Dayak food that uses more indigenous spices and fresh herbs [48].

Sulawesi Island is known for the best sea produce in Indonesia; hence, its culinary taste has revolved around seafood cuisines. Fish roasted over charcoal (ikan bakar) served with a variety of dipping sauce or condiment is a firm regional favourite. Likewise West Sumatra, most of the dishes in North Sulawesi have a very strong flavour that generated from chilli. In addition to this, some dishes in this region serve animals, such as dogs, bat, and forest rats, as the main ingredients of the food [46]. Calling the use of these unusual food as scary food, a study was undertaken to examine the phenomenon of offering scary foods as part of adventure tourism for international visitors not only elicit emotional reactions like fear or disgust but also thrill and enjoyment, dependent upon visitor's personality and motivation for travel [49].

Lastly, the cuisines from Maluku Islands and Papua, which are drier, are similarly defined by seafood. However, the staple food of native people in Maluku and Papua, instead of rice like the other five regions, is papeda (sago congee), usually consumed with yellow soup made from fish such as tuna and mubara fish spiced with turmeric and lime [46].

Table 1 summarises the characteristics and the classifications of Indonesian cuisine mapping which vary across the regions in the country. The map divides the country into three major regions: western, central, and eastern part of Indonesia.

\section{Conclusion}

The preceding review and discussions have shown that Indonesia boasts a long history with diverse influence from different cultures. This diversity has brought significant influences that have supported the establishment of various unique exotic cuisines in the country. This study is anticipated to function as a starter contribution to increase the market awareness of Indonesian cuisine and its richness particularly through the exploration of socio-cultural aspect.

\section{Acknowledgments}

The author would like to thank the reviewers for their valuable inputs to the manuscript to meet the standard of publication of this journal.

\section{Author's contributions}

The author read and approved the final manuscript.

\section{Author's information}

Serli Wijaya is an Assistant Professor at Faculty of Business \& Economics, Petra Christian University, Surabaya Indonesia. She obtained a doctor of philosophy degree from Victoria University, Melbourne. Her research interest is in the areas of tourist behaviour, destination marketing, and special interest tourism including culinary tourism.

\section{Funding}

This study was funded by the Directorate General of the Ministry of Research, Technology and Higher Education, Republic of Indonesia.

Availability of data and materials

All datasets have been presented in this paper.

Competing interests

The author declares that she has no competing interests. 
Received: 23 May 2019 Accepted: 4 September 2019

Published online: 18 September 2019

\section{References}

1. Conner M, Armitage CJ. In: Sutton S, editor. The social psychology of food. Philadelphia: Open University Press; 2002.

2. Bessiere J. Local development and heritage: traditional food and cuisine as tourist attractions in rural areas. Eur Soc Rural Sociol. 1998;38(1):21-34.

3. Henderson JC. Food tourism reviewed. Br Food J. 2009;111(4):317-26.

4. Du Rand GE, Heath E, Alberts N. The role of local and regional food in destination marketing: a South African situation analysis. J Travel Tour Mark. 2003;14(3/4):97-112.

5. Yurnaldi. Pariwisata Indonesia jauh ketinggalan [Indonesian tourism is left behind]. Kompas. 2010; Sect. Travel.

6. Pertiwi NLM. Kuliner Indonesia layak dipromosikan [Indonesian culinary is well-deserved to be promoted]. Kompas. 2011;Sect. Travel.

7. Von Holzen $\mathrm{H}$. The food of Indonesia: authentic recipes from the spice islands. Singapore: Periplus Editions (HK) Ltd; 1996.

8. Giles J, Middleton T. Studying culture: a practical introduction. Oxford: Blackwell Publishers Inc; 1999. 280 p

9. Mennell S, Murcott A, van Otterloo AH. The sociology of food: eating, diet and culture. London: SAGE Publications Ltd; 1992.

10. Kittler PG, Sucher KP. Food and culture. 4th ed. Belmont: Wadsworth/ Thomson Learning; 2004.

11. Hegarty JA, O'Mahony BG. Gastronomy: a phenomenon of cultural expressionism and an aesthetic for living. Hosp Manage. 2001;20:3-13.

12. Sussmann S, Rashcovsky C. A cross-cultural analusis of English and French Canadians' vacation travel patterns. Int J Hosp Manag. 1997;16(2):191-207.

13. Reisinger $Y$, Turner LW. Cultural differences between Asian tourist markets and Australian hosts, part 1. J Travel Res. 2002:40:295-315.

14. Counihan C, Esterik VP. Food and culture: a reader. 2nd ed. New York: Routledge Taylor \& Francis Group; 2008

15. Wahlqvist ML, Lee MS. Regional food culture and development. Asia Pac J Clin Nutr. 2007;16(Suppl 1):2-7.

16. Chang RCY, Kivela J, Mak AHN. Attributes that influence the evaluation of travel dining experience: when East meets West. Tour Manag. 2010;30:1-10.

17. Reynolds PC. Food and tourism: towards an understanding of sustainable culture. J Sustain Tour. 1993;1(1):48-54.

18. Bonicafe P. In: Meethan K, loannides D, editors. Tasting tourism: travelling for food and drink. Hampshire: Ashgate Publishing Limited; 2003.

19. Fischler C. Food and identity. Soc Sci Inf. 1988;27(2):275-92.

20. Edelstein S. Food, cuisine, and cultural competency for hospitality, and nutrition professionals. Sudbury: Jones and Bartlett Publishers; 2011.

21. Allen MW, Gupta R, Monnier A. The interactive effect of cultural symbols and human values on taste evaluation. J Consum Res. 2008;35(August):294-308.

22. Holbrook MB, Hirschman EC. The experiential aspects of consumption: consumer fantasies, feelings, and fun. J Consum Res. 1982;9(2):132-40.

23. Montanari M. The culture of food. Paris: Blackwell Publishers; 1994

24. Tian RG. Cultural awareness of the consumers at a Chinese restaurant. J Food Prod Mark. 2001;7(1-2):111-30.

25. Chang KC. Food in Chinese culture: anthropological and historical perspectives. New York: Yale University; 1977.

26. Beardsworth A, Keil T. Sociology on the menu: an invitation of the study of food and society. London: Routledge; 1997.

27. Chang SY. A cross cultural comparison of food preferences employing risk perception and novelty seeking influences [dissertation]. Townsville: James Cook University; 2007.

28. Long LM. Culinary tourism. Kentucky: The University Press of Kentucky; 2004. p. 306.

29. Sparks B, Bowen J, Klag S. Restaurants and the tourist market. Int J Contemp Hosp Manag. 2003;15(1):6-13.

30. Bell D, Valentine G. Consuming geographies: we are where we eat. London: Routledge; 1997.

31. Koene H. Culinary reconnaissance: Indonesia. Aramco World. 1996;47:18-27.

32. Prince R. The real tastes of Indonesia: a culinary journey through 100 unique family recipes. Melbourne: Hardie Grant Books; 2009. p. 288.

33. Wongso W. Flavors of Indonesia: William Wongso's culinary wonders. Jakarta: Bab Publishing; 2016. p. 198.

34. Taylor JG. Indonesia: peoples and histories. New Haven: Yale University Press; 2003.

35. Fadiati A, Mariani S. Codification of Indonesian culinary: critical analysis of traditional Food. Proceedings of the 3rd UNJ International Conference on
Technical and Vocational Education and Training 2018. Dubai: KnE Publishing; 2019. p. 19-31.

36. Ananta A, Arifin EN, Hasbullah MS, Handayani NB, Pramono A. Demography of Indonesia's ethnicity: Institute of Southeast Asian Studies; 2015.

37. Alamsyah Y. Bangkitnya bisnis kuliner tradisional [the rise of traditional culinary business]. Jakarta: PT. Elex Media Komputindo; 2008.

38. Ho AY. At the south-east Asian table. New York: Oxford University Press; 1995.

39. Setyanti CA. Kuliner Indonesia jadi tren, kini dan nanti [Indonesian culinary, now and then]. Kompas. 2011;Sect. Travel.

40. Tourism MoCa. Indonesia culinary. In: Indonesia MoCaTTRo, editor. Jakarta: Ministry of Culture and Tourism The Republic of Indonesia; 2010.

41. Sovyanhadi M. Indonesia. In: Edelstein S, editor. Food, cuisine, and cultural competency for culinary, and nutrition professionals. Sudbury: Jones and Bartlett Publishers; 2011.

42. Astuti M, Meliala A, Dalais FS, Wahlqvist ML. Tempe, a nutritious and healthy food from Indonesia. Asia Pac J Clin Nutr. 2000;9(4):322-5.

43. Lipoeto NI, Agus Z, Oenzil F, Masrul M, Wattanapenpaiboon N, Wahlqvist ML. Contemporary Minangkabau food culture in West Sumatra, Indonesia. Asia Pac J Clin Nutr. 2001;10(1):10-6.

44. Cheung T. Your pick: World's 50 most delicious foods2011 21 January 2012. Available from: http://www.cnngo.com/explorations/eat/readers-choiceworlds-50-most-delicious-foods-067535. Accessed 25 May 2013.

45. Klopfer L. Padang restaurants: creating "ethnic" cuisine in Indonesia. Food Foodways. 1993;5(3):293-304.

46. Wikipedia. Indonesian cuisine: Wikimedia Foundation, Inc.; 2010. Available from: http://en.wikipedia.org/wiki/Cuisine_of_Indonesia. [cited 201024 September]

47. Asia WD. Borneo foods: what to eat in Borneo: Asia Web Direct; 2012. Available from: http://www.borneo-hotels.com/info/what-to-eat.htm. [cited 20128 October].

48. TravelSmart. Kalimantan restaurants and dining (Kalimantan, Indonesia): TravelSmart Ltd; 2012. Available from: http://www.kalimantan.world-guides. com/kalimantan_restaurants.html. [updated 30 September 2012; cited 2012 8 October]

49. Gyimóthy S, Mykletun RJ. Scary food: commodifying culinary heritage as meal adventures in tourism. J Vacat Mark. 2009;15(3):259-73.

\section{Publisher's Note}

Springer Nature remains neutral with regard to jurisdictional claims in published maps and institutional affiliations.
Ready to submit your research? Choose BMC and benefit from:

- fast, convenient online submission

- thorough peer review by experienced researchers in your field

- rapid publication on acceptance

- support for research data, including large and complex data types

- gold Open Access which fosters wider collaboration and increased citations

- maximum visibility for your research: over $100 \mathrm{M}$ website views per year

At BMC, research is always in progress.

Learn more biomedcentral.com/submissions 